\title{
Correction: Phosphatase of regenerating liver-3 (PRL-3) is associated with metastasis and poor prognosis in gastric carcinoma
}

Xiaofang Xing ${ }^{1 \dagger}$, Shenyi Lian ${ }^{2 \dagger}$, Ying $\mathrm{Hu}^{3 \dagger}$, Ziyu Li ${ }^{4}$, Lianhai Zhang ${ }^{4}$, Xianzi Wen ${ }^{1}$, Hong Du ${ }^{3}$, Yongning Jia ${ }^{4}$, Zhixue Zheng ${ }^{4}$, Lin Meng ${ }^{2}$, Chengchao Shou ${ }^{2^{*}}$ and Jiafu $\mathrm{Ji}^{i^{*}}$

\section{Text}

After publication of this work [1], we found that we inadvertently failed to include the complete title of the affiliation. The full description of affiliation has now been added and the Authors' contributions and Competing interests section modified accordingly.

\section{Competing interests}

The authors declare that they have no competing interests.

\section{Authors' contributions}

XXF and LSY conceived the study, performed most experiment and drafted the manuscript. HY participated in collecting the specimens. LZY and ZLH participated in the clinical data collection. WXZ participated in the manuscript writing and revision. DH carried out celluar studies. ML construceted the expression vector. JYN carried out a part of celluar studies. SCC and JJF conceived the study, participated in its design and gave final approval of the version to be published. All authors read and approved the final manuscript.

\section{Author details}

'Department of gastrointestinal translational research, Peking University, Peking, China. ${ }^{2}$ Department of Biochemistry and Molecular Biology, Peking, China. ${ }^{3}$ Tissue bank, Key laboratory of Carcinogenesis and Translational Research (Ministry of Education) Peking University Cancer Hospital \& Institute, Beijing, China. ${ }^{4}$ Department of gastrointestinal surgery, Key laboratory of Carcinogenesis and Translational Research (Ministry of Education) Peking University Cancer Hospital \& Institute, Beijing, China.

Received: 19 March 2014 Accepted: 19 March 2014 Published: 26 March 2014

\section{Reference}

1. Xing XF, Lian SY, Hu Y, Li ZY, Zhang LH, Wen XZ, Du H, Jia YN, Zheng ZX, Meng L, Shou CC, Ji JF: Phosphatase of regenerating liver-3 (PRL-3) is associated with metastasis and poor prognosis in gastric carcinoma. J Transl Med 2013, 11:309.

doi:10.1186/1479-5876-12-73

Cite this article as: Xing et al:: Correction: Phosphatase of regenerating liver-3 (PRL-3) is associated with metastasis and poor prognosis in gastric carcinoma. Journal of Translational Medicine 2014 12:73.

* Correspondence: scc@bjcancer.org; jiafuj@hotmail.com

${ }^{\dagger}$ Equal contributors

2Department of Biochemistry and Molecular Biology, Peking, China

${ }^{1}$ Department of gastrointestinal translational research, Peking University,

Peking, China

Submit your next manuscript to BioMed Central and take full advantage of:

- Convenient online submission

- Thorough peer review

- No space constraints or color figure charges

- Immediate publication on acceptance

- Inclusion in PubMed, CAS, Scopus and Google Scholar

- Research which is freely available for redistribution

Submit your manuscript at www.biomedcentral.com/submit
C BioMed Central

\section{Biomed Central}

(C) 2014 Xing et al.; licensee BioMed Central Ltd. This is an Open Access article distributed under the terms of the Creative Commons Attribution License (http://creativecommons.org/licenses/by/4.0), which permits unrestricted use, distribution, and reproduction in any medium, provided the original work is properly credited. The Creative Commons Public Domain Dedication waiver (http://creativecommons.org/publicdomain/zero/1.0/) applies to the data made available in this article unless otherwise stated. 